\title{
Czech travelogues about Soviet Russia and the Soviet Union - a neglected source for historical geography
}

\author{
JAROSLAV DAVID ${ }^{1}$ and JANA DAVIDOVÁ GLOGAROV Á ${ }^{2}$
}

\begin{abstract}
This text focuses on Czech travelogues about Soviet Russia (and later the Soviet Union) dating from the period 1917-1968. The material - consisting of 72 published books - provides new insights into the historical perception of the Soviet Union. Most of the books represent the genre of ideological travel literature. They were written not only by journalists, writers and politicians, but also by members of professional delegations, e.g. firefighters, farmers, etc. The authors' approach to the Soviet state changed during the period under investigation - from the initial desire (in the 1920s and 1930s) to uncover the secrets of the world's first socialist state, to the uncritical admiration of the USSR that characterized the travelogues written during the 1950s, in line with official ideological dictates. This text explores the main tendencies that can be found in Czech travelogues about the Soviet Union, tracing how the treatment of key issues developed and changed over time, describing the strategies used by authors when presenting Soviet society and everyday life, and discussing the thematisation of proper names and the Russian language. Four issues of relevance to historical geography are examined: means of transport, itineraries, the depiction of nature, and the linguistic landscape.
\end{abstract}

Keywords: travelogue, travel writing, Czech travelogues, Soviet Russia, Soviet Union (USSR), ideological travelogue

\section{Introduction - travelogues as source material}

Travel reflects human beings' desire to discover the world around them, to explore foreign countries and to uncover these countries' secrets. However, journeys are not undertaken only for purposes of tourism; they may be work-related, diplomatic or propagandistic in nature, or they may be rooted in a desire for adventure. This variety is reflected in the type of literature that can be broadly characterized as travel writing - which may include simple accounts of journeys, colourful depictions, reportage, stylized literary texts, and also fictitious travelogues. These texts vary in their form, in the topics and themes that they foreground, or in their authorial perspective; for this reason travelogues are often described as a hybrid genre, or the more general term 'travel writing' is used instead. However, all these texts are united by a common thread; their authors' attempts to present their own impressions of the destination country to a broad readership, or to create an image of the country in accordance with the author's specific goals, as shaped by his/her personal preferences or ideological requirements (Fussell, P. 1980; Holland, P. and Huggan, G. 2000; Thompson, C. 2011).

This study focuses on travelogues about Soviet Russia (later the Soviet Union) published in Czechoslovakia during between 1917 and 1968. This period occupies a specific position within the tradition of Czech travel writing about Russia. Texts written prior to this period (dating from the Early Modern era

\footnotetext{
${ }^{1}$ Department of Czech Language, Faculty of Arts, University of Ostrava, Czech Republic. 70103 Ostrava, Reální 5. E-mail: jaroslav.david@osu.cz

${ }^{2}$ Centre for Economic and Social History, Faculty of Arts, University of Ostrava, Czech Republic. 70103 Ostrava, Reální 5. E-mail: jana.davidova@osu.cz
} 
and the $19^{\text {th }}$ century) have already been described by a number of scholars (cf. an overview in BorovičKA, M. 2010; recent studies include e.g. Hrabal, J. 2015; ŠvéDA, J. 2016). However, later Czech travel writing on the subject of Russia has only been analyzed sporadically, and still awaits systematic treatment, or it has been used solely as a reservoir of illustrative historical sources (BLAHYNKOvÁ, K. and BlahYNKA, M. 1987; LomíčEK, J. 2011, 2014). This neglect evidently stems from several factors: not only is the period under investigation still relatively recent, but reception of these texts is also negatively affected by the stigma of the ideological burden which most of them carry - and by the fact that some of the texts, especially those from the inter-war period, could not be re-published (even in the form of extracts) under the communist regime (1948-1989).

The material analysed for this study consists of 72 texts, among which we can observe considerable formal differences; the list of references includes only those texts which are cited or referred to in this study (for more details on the complete set of materials see Davidová Glogarová, J. and David, J. 2017). In order to be included in the corpus, the texts had to present an account of a journey based on the author's personal experience, published in book form. The period covered by the corpus is bounded by two major historical milestones: the October Revolution of 1917 (the fall of the Tsarist regime and the beginning of Sovietization) and the occupation of Czechoslovakia by Warsaw Pact troops in 1968; the latter date was followed by a gradual cooling and formalization of CzechSoviet relations that was reflected in a sharp decline in the number of travelogues about the Soviet Union and a general lack of interest in visiting the country (BAGDASARYAN, V.E. et al. 2010; LомíčEK, J. 2015).

Travelogues are a distinct type of text presenting Soviet Russia (and later the Soviet Union), and as such they represent an extensive source of material that reflects the changing attitudes (and illusions) of Czechoslovak society with regard to Soviet Russia and the
USSR during the course of the $20^{\text {th }}$ century; these changes reflected fluctuations in the cultural and political climate. In view of the broad readership at which these texts were aimed, they can be considered an important medium which helped to shape the ideological image of Soviet Russia and the USSR whether pro-Soviet or (less frequently) antiSoviet. From this perspective, travel writing about the USSR forms part of a distinct body of work known as 'ideological travelogues' - texts whose purpose was to present, create and reinforce an ideologically biased and tendentious image of the destination country. Ideological travelogues can be further divided into texts written by authors who were supportive of the regime in the destination country (fellow travellers) and those who were opposed to it (anti-fellow travellers) (Behrends, J.C. 2009; Khmelnitsky, D. 2011). It is thus understandable that nondemocratic regimes during the $20^{\text {th }}$ century engaged in the targeted, orchestrated use of travelogues as a propaganda tool.

For example, Goebbels' propaganda minister in Nazi German used its Nibelungen Verlag publishing house (1934-1941) to publish several travelogues presenting eyewitness accounts by visitors to the USSR - especially those that reported negative experiences of Soviet life (anti-fellow travellers). One of the most important texts of this type is a book by the German author Karl Iwanowitsch Albrecht (originally a communist, who later defected to the Nazis) entitled Der verratene Sozialismus [Socialism Betrayed] (1938). The text gives a detailed account of the ten years Albrecht had spent living in the USSR and working as a high-ranking state official there. The Soviet Union also used travelogues for ideological purposes, as a means of promoting communist ideology.

The writer Maxim Gorky returned to the USSR from Italy on several occasions during the 1920s, visiting the prisoners' commune of Bolshevo (1928) and the gulag at Solovki (1929); based on these journeys, he wrote five volumes of reportage that were later published in book form as Po Soyuzu Sovetov [Around the Soviet Union] (YeduIn, P. 1999). In the second 
half of the 1930s, as a direct response to the publication of André Gide's highly critical Retour de l'U.R.S.S. [Return from the USSR] (1936), the Soviet authorities invited the German author Lion Feuchtwanger to visit the country; Feuchtwanger willingly expressed his approval for the Soviets' political show-trials (in the travelogue Moskau 1937, 1937; DAvidFox, M. 2012). The importance of ideological travelogues as a means of promoting the Soviet Union among Czech readers is evident from the existence of the publishing house Svět sovětu [The World of the Soviets] (1948-1968), which was established soon after the communists' seizure of power. Its main focus was on translations (primarily from Russian) of fictional texts and educational literature, but it also published a series of travelogues by Czech authors as part of its series entitled SSSR našima očima [The USSR through our Eyes].

Travel writing can be used as source material in many scholarly disciplines - not only historiography and literary history, but also anthropology and linguistics. Particularly since the 1990s, there has been an upsurge of interest in travelogues among scholars as part of the development of space studies (see e.g. Heeke, M. 2003; BorovičKa, M. 2010). The analysis of travelogues can also bring insights for geographers (and historical geographers), especially with regard to the changing image of the Soviet Union and travel writing over the course of time.

\section{Czech interest in Russia and the Soviet Union from the perspective of travel writing}

Czech travellers' interest in Russia began to grow at the end of the $18^{\text {th }}$ century, culminating in the $19^{\text {th }}$ and $20^{\text {th }}$ centuries. During the $19^{\text {th }}$ century, travel writing about Russia was strongly influenced by national ideology and the notion of Slavic unity under the patronage of the Tsarist empire (Russophile and pan-Slavic tendencies) (BorovičKA, M. 2010). The range of authors was already quite broad, including not only intellectuals but also adventurers and gold prospectors. One of the best-known is the writer and journalist Karel Havlíček Borovský, who travelled to Russia in 1843-1844. He too was initially a fervent pan-Slavist, but his innately critical view of the world alerted him to the inadequacies of Russian society, and he soon lost his former idealism. However, his Obrazy z Rus [Pictures from Russia] (published as a book in 1870) was an exception to the general rule; the majority of Czech authors expressed admiration for Russia. At the turn of the $20^{\text {th }}$ century, Josef Holeček's Zájezd na Rus [Journey to Russia] $(1896,1903)$ contrasted the decadent, moribund Western civilization with the healthy, natural society he saw in Russia. More critical and realistic depictions were given by Vilém Mrštík in a series of articles entitled Listy z Nižního Novgorodu Rus [Letters from the Russia of Nizhniy Novgorod] (1869, not published in book form until 1992), and shortly before the First World War - by Zdeněk Matěj Kuděj, whose journey to Russia, though brief, convinced him that the image of the Czech nation in Russia was far removed from the wishful thinking of many Czechs.

After the October Revolution of 1917, Czech attitudes to Russia underwent a fundamental transformation. Soviet Russia - a society in the throes of radical and tumultuous political and social change - once more became an essentially unknown country for Czech intellectuals, a country that had to be 'discovered' all over again and presented afresh to Czech readers. The attraction of Soviet Russia for Czech writers was strengthened not only by the contradictory reports appearing in the media (and the general lack of information), but also by the myth of freedom that was associated with communism (BorovičKA, M. 2010). This attraction was further enhanced by the fact that the public image of the United States as the "land of the free" had suddenly come under threat from the Soviet Union, resulting in a discursive "struggle for America" (ŠvéDA, J. 2016).

Among the manifestations of Czech society's desire to cement mutual relations and raise awareness of Soviet Russia were the establishment of various associations promoting Czechoslovak-Soviet friendship and 
the journeys undertaken by official delegations or organized tourism (LoмíčEK, J. 2014; BAgDASARYAN V.E. et al. 2010). This thirst for knowledge affected all strata of society; the authors of travelogues included not only writers and journalists but also politicians, artists and manual labourers. Writing about their preparations for the journey, authors focused on their keenness to experience Soviet Russia for themselves, though in some cases - such as the former members of the Czechoslovak Legion who had fought against the Bolsheviks in the Russian Civil War - the travellers were highly apprehensive about how they might be received there.

The manner in which Soviet Russia was ultimately presented in the travelogues depended primarily on each author's own political stance. We can identify two distinct streams in travel writing from this period. Some authors belonged to the leftist avant-garde; in the 1920s these included Ivan Olbracht and Marie Majerová, and in the 1930s Julius Fučík and Marie Pujmanoví (Photo 1).

Other authors, such as Josef Kopta or Helena Bochořáková-DitTrichová (1934) expressed doubts over the direction in which the Soviet Union was heading. Between these two opposite poles there was a large group of authors for whom Soviet life was in many ways a pleasant surprise, but who were nevertheless willing to depict its downsides. The ultimate purpose of the journey was to enable the all authors to offer a brief 'snapshot' description of the still-unknown Soviet world for the benefit of Czech readers.

The publication of André Gide's critical account Retour de l'U.R.S.S. [Return from the USSR] (1936; published in Czech as Návrat ze Sovětského svazu, 1936) sparked a polemic in Czech intellectual circles. The growing threat of fascism caused many intellectuals to fear that critical views of the USSR could potentially be misused by anti-democratic forces for their own ends (Hollander, P. 2014), and - against the background of the dramatic events of 1938-1939 - the late 1930s brought a halt to the publication of travelogues about the Soviet Union.

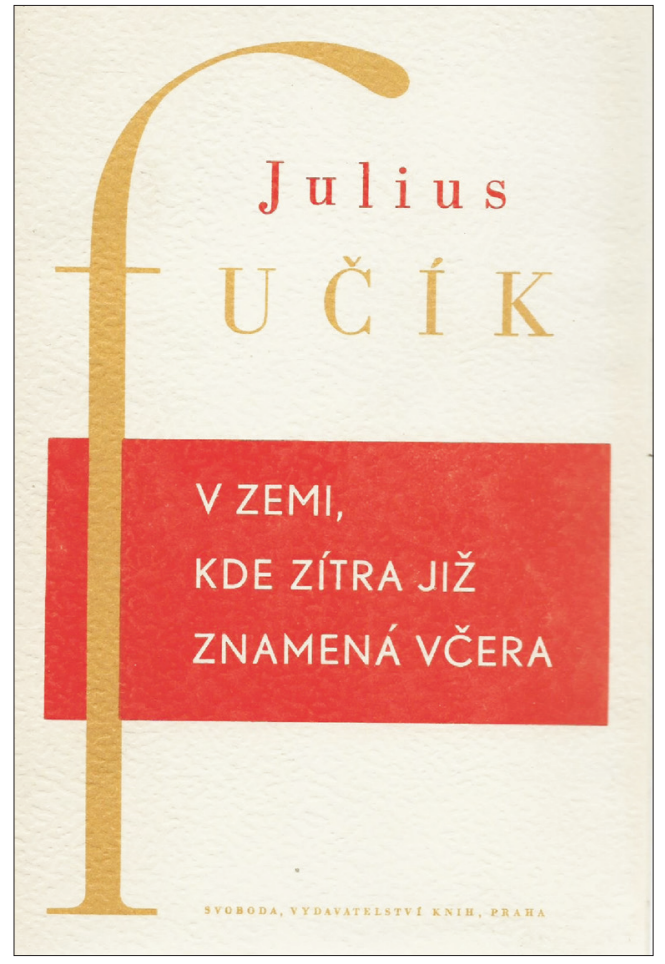

Photo 1. Julius Fučík's book (1932) represents a pure example of ideological pro-Soviet travelogue. The cover of its $2^{\text {nd }}$ edition (1950).

After 1945, the status of the Soviet Union as a victor over fascism brought a radical change in Czech attitudes to the USSR, which was now viewed unquestionably as a liberator and as a truly global power. In the context of subsequent developments on the domestic political scene (the communists' seizure of power in 1948), it is understandable that travel writing about the USSR published in the late 1940s and throughout the 1950s took an unswervingly pro-Soviet line. One of the typical features of travel writing during this period was therefore its homogeneity, a result of the authors' own ideological bias and the fact that laudatory, uncritical admiration was the only officially permitted stance towards the USSR. However, as in the interwar period, authors from these years belonged to various different professions - including not only the members 
of specific agricultural delegations, but also writers, journalists, theatre actors and directors, musicians, firefighters and more (Photo 2).

The writers' keenness to visit the USSR was no longer primarily motivated by a desire to discover and write about a new country, but rather by their joyful expectation of visiting a destination for which they already felt an almost sacred admiration - or at least this was the impression created by their prose. The destination that they were about to visit was no longer an unknown quantity; the Soviet Union was presented as a close friend, or as a teacher and guide. Visitors were about to enter a utopian world of which they had already formed a mental image back home in communist Czechoslovakia. This image of the Soviet Union remained dominant up to the 1960s, and even during the 1960s it persisted in the majority of travel writing. However, the gradual liberalization of political and cultural life during the 1960s made it possible for authors to voice critical opinions. In the mid1960s, travellers' interest in the Soviet Union began to wane in favour of other countries, particularly Western Europe and Asia.

In the following section we focus on four topics (means of transport, itineraries, the depiction of nature, and the linguistic landscape) which demonstrate the potential of travel writing as a source of material for historical geography; these are also the aspects of the texts which show the greatest range and variation throughout the period under investigation (for more details see DAvidová Glogarová, J. and David, J. 2017).
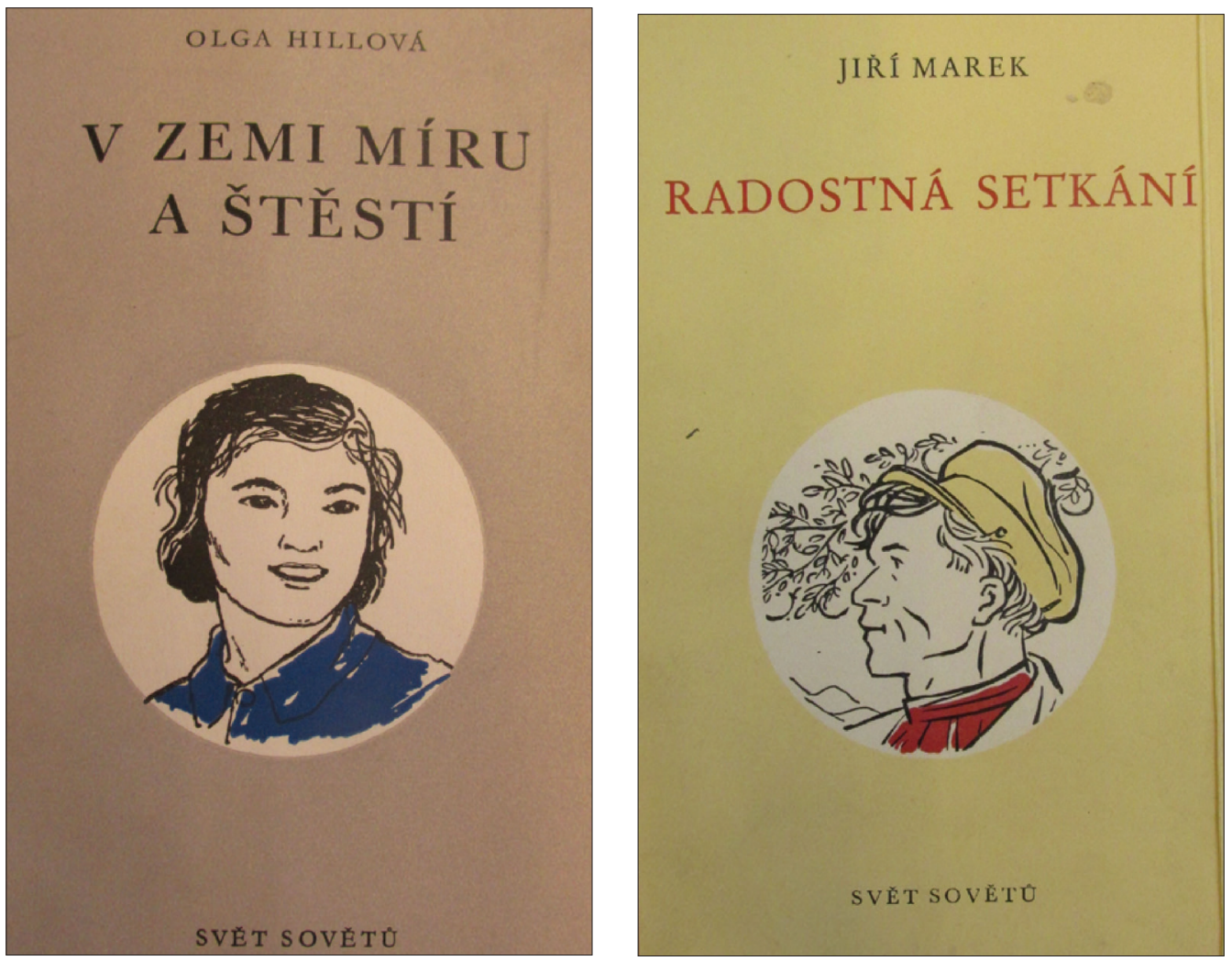

Photo 2. Covers of travelogues from the 1950s 


\section{Means of transport}

It was not only perceptions of the Soviet Union that changed during the course of the $20^{\text {th }}$ century, but also the means and forms of transport used by travellers. During the inter-war period, the authors travelled to the USSR by train, usually via Poland. Their descriptions of the journey include accounts of meeting and talking with other travellers from all over Europe - who, especially during the 1920s, often warned them of the chaos that the revolutionary events had brought. Most of the travellers entered Soviet territory at the Nyegoreloye border post, which was presented as both a real and a symbolic boundary separating the old world from the new (the barbed-wire enclosure; the boundary of the world; the boundary between the Western and Eastern worlds). This sense of a momentous occasion was reinforced by the change of time zone (clocks went forward by two hours), which - together with the prominently displayed symbols of communism - represented an entry into a new space-time: "Move the clock forward by two hours, change trains for the wide-gauge Soviet carriages with the conductress, and you are no longer in third class, but in a log cabin. So much wood!" (Pujmanová, M. 1932).

The Soviet soldiers, barbed wire barriers, red stars and propaganda slogans accompanied the travellers throughout their entire journey, and seeing them for the first time enhanced the magic of the moment at which they crossed over to 'the other side of the world': "We crossed from the empire of the bourgeois dictatorship to the empire of the proletarian dictatorship [...] Above the watchtower right on the border flies a red flag, and on its side, facing Estonia and the entire world, the words are clearly visible: 'Workers of the World, Unite!'” (ŠMERAL, B. 1920).

After the Second World War, air transport began to rival the railways in importance. A delegation of Czechoslovak writers flew to the USSR as early as 1948, and in 1949 Jan Bureš remarked: "Travelling to the Soviet Union by train is gradually becoming old-fashioned. It was only the weather that prevented us from flying" (BUREš, J. 1949). Travellers ap- preciated the speed of air travel, which intensified their overall experience, as well as the opportunity to enjoy a bird's-eye view of the landscape. Another change was the westward shift of the Soviet border ('de facto' in 1939, 'de jure' in 1945); the border crossing was no longer at Nyegoreloye, but at the originally Polish town of Brest-Litovsk.

Another change in depictions of transport came in the 1960s. Air travel was still the predominant mode of transport, but the joy of flight was no longer at the forefront of the authors' minds; instead they tended to emphasize their respect for the fact that planes offered access to almost every part of the Soviet Union. Writers praised the advantages of air transport, displayed their knowledge of common types of Soviet planes, and emphasized the speed with which the USSR's transport infrastructure was being constructed, reducing travelling times and enabling Soviet civilization to spread and flourish: "How are you travelling? By plane? It's under two hours to Nepostizhny [...] Years ago it took us twenty-five days or more to get from there to Yakutsk. Across the taiga, and on river boats. There was no other way of getting there." (NoHÁč, Z. and Ововкки́, S. 1961). Most writers continued to be impressed by air travel, which deepened their respect for the great progress achieved by Soviet science and technology. However, for some authors air travel had entirely lost its magic, and they increasingly preferred traditional modes of transport such as trains or ships: "But gone are the days when people sat gaping in their seats, excitedly speculating whether the plane had already left the ground. Nowadays plane travellers doze glumly. The more sophisticated the technology, the greater the boredom [...]" (MAREK, J. 1962).

Besides public transport (trains, planes, boats or ships), the late 1950s - and especially the 1960s - saw the emergence of the private car as a viable means of transport for travellers. Cars freed travellers from organizational constraints and allowed them to discover the country at their own pace, though they were still assisted (and monitored) by the Soviet travel agency Inturist. The experienced traveller František Alexander Elstner drove a 
Škoda Octavia car on his promotional trip through the USSR; an important aim of the trip was to map the country's potential as a destination for motoring tourism (including tourist services and accommodation, the quality of the road network, the prices of food and petrol, etc.) (Photo 3 and 4).

\section{Itineraries}

Due to the close supervision of official delegations and tourist groups, the large distances that had to be covered, and the restricted transport options open to the visitors, the itineraries described in the texts from the inter-war period and the 1950s are often very similar - encompassing visits to social and government institutions, factories, new buildings, museums, and former churches and monasteries that had generally been converted into museums of atheism and similar

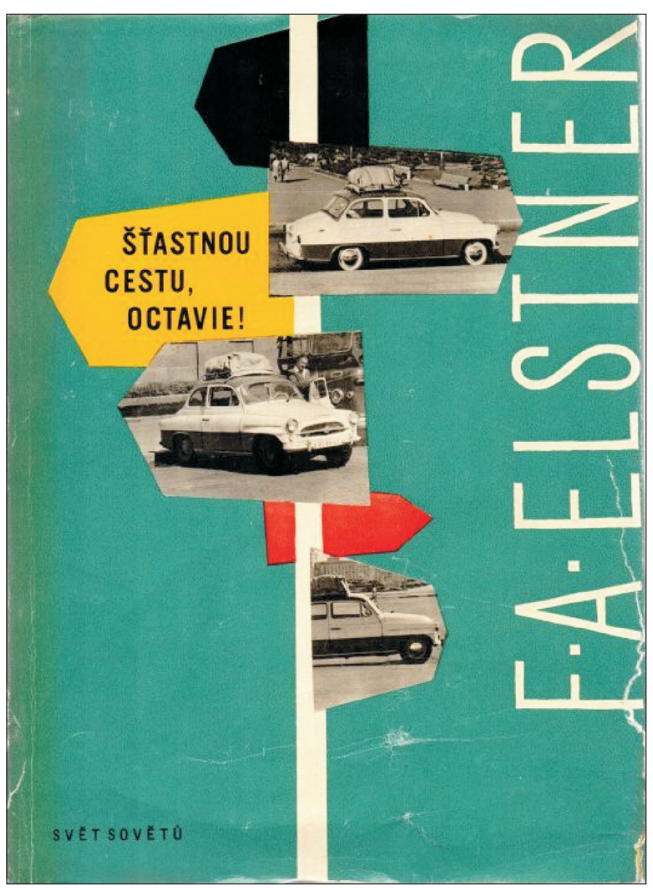

institutions. Above all, it was essential for the authors to visit the cities that were perceived as the 'cradles of the Revolution' - Moscow, Leningrad (up to 1924 and from 1991 Sankt Petersburg), and later Stalingrad (up to 1925 Tsaritsyn, from 1961 Volgograd). Other important destinations included Kiev and Kharkov. The authors described the overall character and atmosphere of these cities in order to give their Czech readers an impression of everyday Soviet life.

The large cities in the European part of the Soviet Union continued to be the most frequent destinations for authors visiting the country after the Second World War, with Leningrad and Stalingrad gaining in popularity. The authoritative status of Leningrad in the post-war years was described in emotive terms by Jarmila Glazarová: "In the autumn of '41 Leningrad set up radio contact with Sevastopol, and both cities remained in contact until Sevastopol had to surrender. In 1944 they told us how they felt a strange trembling when they heard the voice from Leningrad, because it was the voice of a brother in distress. The voice of an elder brother" (Glazarová, J. 1952b). However, the greatest prestige and honour was enjoyed by Stalingrad, "a witness to the immortal glory and heroism of the Soviet people, where from the ruins, from the land soaked in the blood of heroes, a new city is born, a city of creative labour" (Hillová, O. 1951); Stalingrad became one of the central symbols of communism, and the city was personified as the saviour of the Soviet Union from the threat of Nazism.

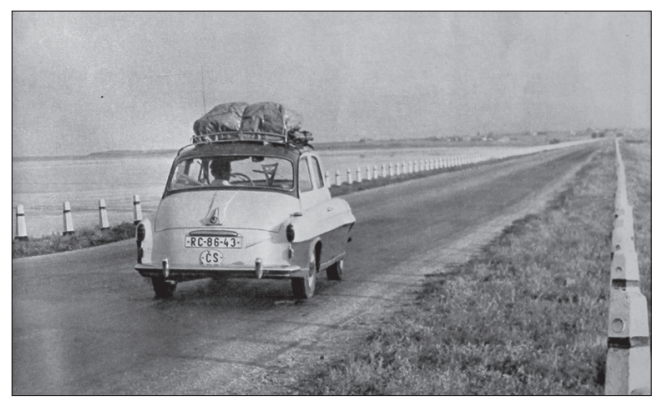

Photo 3-4. František A. Elstner's travelogue (1961) describing a Škoda Octavia car promotional trip through the USSR. 
After the Second World War, the development of air transport infrastructure opened up the more distant Asian part of the Soviet Union to travellers. Authors undertook journeys not only to the Caucasus and the Black Sea coast, but also to Central Asia, the Urals and Siberia; these destinations were particularly favoured by delegations from agricultural collectives. The more distant and exotic regions of the Soviet Union became common destinations in the 1960s, even surpassing the large cities in the European part of the country. Authors appeared unwilling to write repeatedly about places which had already been written about numerous times since the Revolution, and which many of them had themselves already visited on numerous occasions.

By the early 1960s, the large Soviet cities seemed no more exotic and interesting to the authors than Prague did. This is evident from a travelogue written by Josef KADLEC, for whom Moscow was almost a second home, a city where he had many friends and favourite places: "I don't feel like sleeping, and it wouldn't seem right to spend my first evening in Moscow alone. So I look through my book of phone contacts, there's a phone on the table-all I need to do is dial a number and call someone, say hello to them. I feel like doing that..." (KADLEC, J. 1960). However, most Czech visitors felt more attracted to places that remained unexplored - and there were still many such places in the Soviet Union. The traditional tourist sites and organized Inturist itineraries prevented them from reaching their real destinations, and the authors felt them to be a waste of time: "Two whole days in Kiev? That's a whole hike in the Caucasus! 'Can't we shorten it?' We have our instructions.' 'But your instructions are costing us two days in the mountains.'" (HeckeL, V. and Černík, A. 1965).

Travelling to the more distant regions of the Soviet Union represented an opportunity to explore unknown territory and open up new vistas. The authors described the geography of the places they visited, gave historical accounts and described local traditions, met and spoke with local people, and told their stories.

\section{The depiction of nature}

The authors of travelogues described not only urban destinations, but also landscapes and the natural world. Members of the left-wing avant-garde placed particular emphasis on the industrial landscape, transformed and shaped by human activity; this tendency began in the inter-war years and became even stronger during the 1950s. Their focus was no longer on rivers, but dams; no longer on traditional rural life, but on collective farms and especially on the people who laboured to fulfil the five-year plans. Landscapes in which the natural world was combined with anthropological features became an ideological image celebrating the triumphant achievements of mankind, in the spirit of Stalin's plans to harness and transform nature. These plans proved particularly inspirational to the members of agricultural delegations who visited the USSR in the 1950s. Air travel also offered a bird's-eye view of the land, emphasizing the spatial otherness of the Soviet Union. A striking image observed by some travellers was the contrast between the huge collective fields and the narrow strips of privately owned farmland: "When travelling from BrestLitovsk to Moscow, our delegates observed how the landscape changed. From Minsk onwards we could see from the train that we were in another country, where agriculture had progressed beyond the individual level. There were no small fields like at home or in Poland, but only huge tracts of farmland worked by tractors" (MALík, Z. 1950).

The thematisation of nature and landscape was at its strongest in the travel writing published during the 1960s. Most of the travelogues from this decade continued to depict nature as something that was being successfully cultivated ("The Taiga is being pushed back by the will of the Soviet people. Under its roots lies an immense treasure-chest, and people are now starting to lift up the lid", NoHÁč, Z. and Ововsки́, S. 1961), and some authors viewed nature through a technocratic lens, either as an enemy of mankind or as a mere repository and source of raw materials and energy ("It is almost as if Mother Nature has done this on 
purpose: in this icy land, only rarely visited by the nomadic reindeer herders, the Nganasan and the Sakha, stand two mountains side by side, a unique treasure-chest of valuable mineral resources", NoнÁč, Z. and ОвоRsки́, S. 1962). However, many authors also marvelled at the natural beauty of the landscapes they saw - which were entirely unlike the familiar landscapes of Central Europe. This perspective was particularly typical of the travelogues written by sportspeople (particularly those involved in mountain-climbing and water sports; see Photo 5), who praised the magnificence of the Soviet landscape and admired its rugged peaks and untamed rivers.

These authors - and the local people they met - did not battle against nature, but instead tried to understand it, and their travelogues depicted a symbiosis of mankind and the natural world. They did not praise the

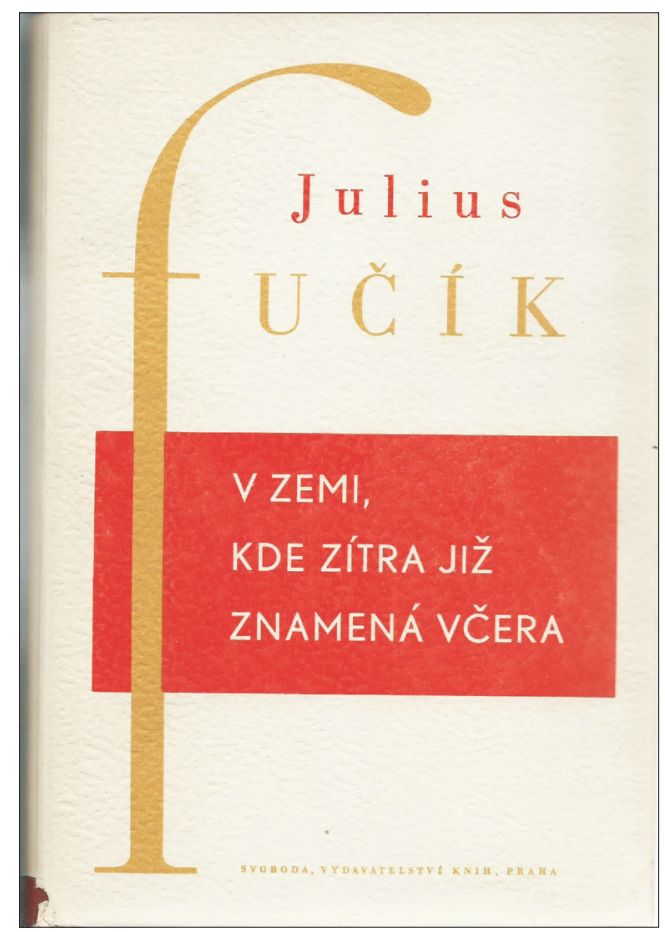

Photo 5. Travelogues written by sportspeople during the 1960s praised the magnificence of the landscape and admired its rugged peaks great Soviet building projects, but cautiously criticized them for disturbing the fragile balance between mankind and nature: "Several kilometres upriver there is now a new village Novyye Bezingi. It consists of several dozen squat, neat-looking whitewashed houses, several stables, sheep-farm enclosures, telephone pylons, electric streetlamps and roads. The builders were not particularly interested in whether the houses fitted into the landscape. New houses were needed, and here they are" (HECKel, V. and ČERNíK, A. 1965). The propagandistic function of these texts was weaker than in other types of travelogues, as if the importance of communism (with its relatively short history in both Czechoslovakia and the USSR) paled into insignificance when faced with the eternal power of nature.

\section{The linguistic landscape}

The authors' attention was also attracted by changes in language, particularly its appellative and proprial components, and the linguistic landscape of written texts in public spaces, which were viewed as symbols of the Revolution. The revolutionary events had not only brought new anthroponyms (personal names), toponyms (geographical names) and other new words into the Russian language; they had also caused shifts in the meanings of existing words. Noticing these changes, the authors tried to explain them - especially during the inter-war years. The new words were attributed performative, symbolic and evaluative functions, as can be seen in this text by Marie Pujmanová: "The Russian word for 'education' [prosveshchenie - 'enlightenment'] still contains its original root: the word meaning 'light'. Words here retain their original meanings. People here believe in them literally. The 'winged words' of Marx and Lenin fly freely here, covering immense distances" (Pujmanová, M. 1932).

The travellers also took an interest in words and phrases connected with the new social and economic reality - Bolshevik, kindergarten, collectivization, kolkhoz, comintern, five-year plan, sotsgorod - or new forms of address. Authors saw a performative function 
in various aspects of Soviet language; $\mathrm{KISCH}$ wrote about the use of diminutive forms to denote police officers ("they use the word 'miltoshka' to mean a member of the people's militia - a diminutive form, whereas the Tsarist gendarmes were viewed as vengeful tyrants, and they were known as 'pharaohs' or 'archangels'", KIsch, E.E. 1929), while Jarmila Glazarová considered why the original word police had been replaced ("Police officers and traffic officers are known here as the 'militia'. The word 'police' had such terrible associations, dating from Tsarist times, that it simply ceased to exist", Glazaroví, J. 1952a).

In addition to thematising the lexical and semantic specifics of appellative vocabulary, the travelogues also devoted considerable attention to proper names, which were seen as manifestations of the new Soviet reality and the people's victory over space and nature. In addition to 'revolutionary' proper names (e.g. Elektrifikatsia ['Electrification'], Oktyabr and Oktyabrina [masculine and feminine forms of 'October'], Revolutsiya or Traktor), authors also wrote about the changes in chrematonyms (new names of shops, companies and institutions) and especially toponyms (new geographical names, including renaming of existing places; on the creation of political landscapes through commemorative names cf. e.g. DAvid, J. 2011).

Especially in the travelogues written between the wars and soon after the Second World War, the authors saw these new names as manifestations of the Soviet dream becoming a reality, underlining the contrast between the new names and the original names; the new names gained a symbolic function and embodied the presence of the future in everyday reality. This perspective can be illustrated by extracts from Julius Fučík's interwar travelogue and a post-war text by Jaroslav VojtĚch: "The history of Tsaritsyn has come to an end. Never, never forget! A new era is flowing above Stalingrad" (Fučík, J. 1932); “We did not have very high expectations of Saratov - perhaps because it still bore its old name. We imagined Saratov as an old Volga town in which nothing much had changed" (VоJтЕ̌cH, J. 1952).
A stylistic technique used by some authors was that of onomastic allusions (LenNon, P. 2004). This technique was used when comparing Soviet cities and regions with locations in other countries (especially in the West and in Czechoslovakia) which were renowned for their historical or cultural significance or which symbolized luxury and wealth. In such cases the metaphor served a propagandistic purpose, and indeed this technique is still used today in advertising (place branding and place marketing); its purpose was to emphasize the progressive nature of Soviet society, which was not only equal to, but superior to the West. An example can be found in a text by GlazArová, J. whose characterization "Vasilyevsky Island is the Soviet Quartier Latin, Leningrad's Latin Quarter" (Glazarová, J. 1952b) not only emphasizes the similarity with the famous Parisian university district, but also accentuates the Soviet character of the Leningrad location. Similarly, the description of Moscow as the third Rome or the Rome of the East emphasizes not only the city's unique character, but also its supremacy.

\section{Conclusions}

Russia was already an interesting destination for Czech travellers in the $19^{\text {th }}$ century, attracting especially those visitors who were inspired by the ideas of pan-Slavism and the cultivation of close mutual relations between the Czech and Russian nations. However, the major impetus for Czech authors' increased interest in Russia was the 1917 Bolshevik Revolution, which ushered in a radically different political and social situation and led to a marked increase in the volume of Czech travel literature about Russia. For visitors from Czechoslovakia, Soviet Russia (from 1922 onwards the Soviet Union) represented an entirely new and exotic destination.

Travelling to post-Revolutionary Russia, they were entering an unknown space; they attempted to uncover its secrets by visiting large cities and observing the behaviour of 
Soviet citizens and the social and economic conditions in which they lived. The main focus for most Czech travelogues during the inter-war period was therefore on depicting the exotically different world of the "Soviet Orient". This focus shifted after 1945 (and particularly after the communist takeover of Czechoslovakia in 1948). Once Czechoslovakia had fallen within the Soviet sphere of influence, travelogues were no longer written in order to convey genuine knowledge and insight to their readers, but instead to strengthen Czechoslovak-Soviet relations and express admiration for the Soviet Union.

Travelogues from this period are characterized by an uncritical pro-Soviet stance and a view of the USSR as a "big brother"; this was also reflected in the texts' depiction of space, which was used to exert ideological persuasion on readers. Examples of this can be found in the authors' descriptions of cities (such as the adoration of Stalingrad as the city that saved the world from fascism) and the natural world (which was depicted purely as an object to be cultivated by human beings, in the spirit of Stalin's plan to transform nature).

A turn away from this type of writing came in the early 1960s, when the development of more sophisticated transport infrastructure (including air transport) and the relaxation of the formerly hard-line communist regime in Czechoslovakia (and also in the USSR) inspired travellers to explore the exotic aspects of the Soviet Union and penetrate deeper into its Asian regions. Some travelogues from this period remained within the tight ideological constraints of the previous era, but others managed to move beyond the ideological conception of space - exploring the beauty of the natural world and the cultures of the USSR's traditional Asian nations.

Focusing on topics connected with the conception of space and landscape (including linguistic landscape), we have set out to show how Czech travelogues published between 1917 and 1968 presented and reflected the developing relationship between Czechoslovakia and the Soviet Union. Travel writing on the USSR continued after 1968 too, though interest in the country declined markedly as Czechoslovak society began to view the Soviet myth with more critical eyes following the Warsaw Pact invasion of 1968 and as the relations between the two countries became more formal in nature; for instance, the 1975 travelogue My z Orenburgu [We of Orenburg] by the pro-regime journalist Jiří Stano represented an attempt to revive the professional travelogue of the Stalinist era.

An analysis of travelogues about Russia published after the fall of the Iron Curtain would undoubtedly have brought interesting insights; this remains a stimulating challenge for future researchers, including historical geographers. Several Czech travelogues have now been published about post-Soviet Russia and its society; these texts also acquaint readers with exotic and adventurous aspects of the country (especially Siberia).

\section{REFERENCES}

BAgdASARYAN, V.E. et al. 2010. Sovetskoye zazerkarle. Inostrannyy turizm $v$ SSSR $v$ 1930-1980-e gody (The Soviets from behind the mirror. Foreign tourism in the USSR in the 1930s-1980s period). Moskva, FORUM.

Behrends, J.C. 2009. Back from the USSR. The AntiKomintern's Publications about Soviet Russia in Nazi Germany (1935-1941). Kritika. Explorations in Russian and Eurasian History 10. 527-556.

Blahynková, K. and Blahynka, M. eds. 1987. Dobrá zvěst (A good tiding). Praha, Československý spisovatel.

BorovičKa, M. 2010. Velké dějiny zemí Koruny české. Cestovatelství (A great history of the lands of the Bohemian crown. Travelling). Praha-Litomyšl, Paseka.

DAvid, J. 2011. Smrdov, Brežněves a Rychlonožkova ulice. Kapitoly z modern české toponymie (Smrdov, Brežněves and Rychlonožkova Street. Chapters on modern Czech toponymy). Praha, Academia.

Davidová Glogarová, J. and David, J. 2017. Obrazy $z$ cest do země Sovětů (Images from journeys to the land of the Soviets). Brno-Ostrava, Host-Ostravská univerzita. (Manuscript in print.)

David-Fox, M. 2012. Showcasing the Great Experiment. Cultural Diplomacy and Western Visitors to the Soviet Union, 1921-1941. New York, Oxford University Press.

Fussel, P. 1980. Abroad. British Literary Travelling Between the Wars. Oxford, Oxford University Press. 
Heeke, M. 2003. Reisen zu den Sowjets. Der ausländische Tourismus in Rußland 1921-1941 (Travel to the Soviets. Foreign tourism in Russia, 1921-1941). Münster, LIT Verlag.

Holland, P. and Huggan, G. 2000. Tourists with Typewriters. Critical Reflections on Contemporary Travel Writing. Ann Arbor, University of Michigan Press.

Hollander, P. 2014. Political Pilgrims. Western Intellectuals in Search of the Good Society. New Brunswick-London, Transaction Publishers.

Hrabal, J. ed. 2015. Fenomén cestopisu v literatuře a umění střední Evropy (Travel in the literature and art in Central Europe). Olomouc, Univerzita Palackého.

Khmelnitsky, D. 2011. The USSR through the Eyes of the Third Reich. Nazi-Age German Literature on the Soviet Union; Truth and Invention. In Totalitarianism and Literary Discourse. $20^{\text {th }}$ Century Experience. Ed.: Ratiani, I., Newcastle upon Tyne, Cambridge Scholars Publishing, 103-115.

Lennon, P. 2004. Allusions in the Press. An Applied Linguistic Study. Berlin, Mouton de Gruyter.

Loмíčeк, J. 2011. Jen v zemi milionů je radost, krása, ráj... Obraz sovětské utopie v diskurzu československých sympatizantů SSSR ve třicátých letech 20. století (There is happiness, beauty, paradise in the country of millions only... An image of the Soviet utopia in the Czechoslovak fellow-traveller's discourse in the course of the 1930s). Kudéj 12. (1): 9-39.

LomíčEK, J. 2014. Poznávací zájezdy československých občanů do sovětského Ruska v meziválečném období z pohledu archivních pramenů Ruské federace (Czechoslovak citizen's tours of the Soviet Russia in the mirror of the Russian Federation archival sources). Časopis Národního muzea. Ǩada historická 183. (3-4): 75-88.

LoмíčEK, J. 2015. Se Sovětským svazem na věčné časy? Proměny vnímání SSSR v Československu v průběhu „krátkého“ dvacátého století (With the Soviet Union everytime? Development of the USSR perception in Czechoslovakia during the "short" $20^{\text {th }}$ century). Sborník Národního muzea v Praze. Řada A-Historie 69. (1-2): 5-18.

ŠvéDA, J. 2016. Země zaslíbená, země zlořečená. Obrazy Ameriky v české literatuře a kultuře od poloviny 19. století k dnešku (Promised land, accursed land. Images of America in Czech literature and culture). Příbram, Pistorius \& Olšanská.

Thompson, C. 2011. Travel Writing. Abingdon, Routledge.

Yedlin, T. 1999. Maxim Gorky. A Political Biography. Westport, Praeger Publishers.

\section{TRAVELOGUE SOURCES}

BochořÁkOvÁ-DitTrichová, H. 1934. Dojmy z SSSR (Impressions from the USSR). Brno, Exod.

Bureš, J. 1949. Sovětské zápisky (Soviet commentaries). Praha, Svět sovětů.

Fučík, J. 1932. V zemi, kde zítra již znamená včera. (In a land where "tomorrow" already means "yesterday“). Praha, Karel Borecký.

Glazarová, J. 1952a. Dnes a zítra. Fejetony (Today and tomorrow. Newspaper feuilletons). Praha, Československý spisovatel.

Glazarová, J. 1952b. Leningrad. Praha, Státní nakladatelství dětské knihy.

Heckel, V. and Černík, A. 1965. Expedice Kavkaz (The Caucasus expedition). Praha, Svět sovětů.

Hillová, O. 1951. V zemi míru a štěstí (In the land of peace and happiness). Praha, Svět sovětů.

Kadlec, J. 1960. Moskevský čas (Time in Moscow). Praha, Svět sovětů.

KIsch, E.E. 1929. Caři, popi, bolševici (Tsars, priests and bolsheviks). Praha, Pokrok.

Malík, Z. 1950. Země přetvořená kolektioní prací (The land reshaped by collective work). Pardubice, Krajské nakladatelství.

MareK, J. 1962. Úsmězné pobřeží (The funny coast). Praha, Svět sovětů.

Noнáč, Z. and Ововsки́, S. 1961. Všude byla tajga (The taiga was everywhere). Praha, Státní nakladatelství politické literatury.

Noнáč, Z. and Овоrsќ́, S. 1962. Vlaky jedou na východ (Trains go to the East). Praha, Nakladatelství politické literatury.

Pujmanová, M. 1932. Pohled do nové země (A view into a new country). Praha, Knihovna Levé fronty.

Šmeral, B. 1920. Pravda o sovětském Rusku (The truth about Soviet Russia). Praha, Ústřední dělnické nakladatelství.

VoJTĚch, J. 1952. Magistrála komunismu (The communism highway). Praha, Svět sovětů. 